\title{
Implementation of Physics Learning Materials Based Generative Learning With Open-Ended Problem Approach To Stimulate Critical Thinking Skills
}

\author{
Chichi Rahayu ${ }^{1}$, Eliyarti ${ }^{2}$ \\ Faculty of engineering and planning of Ekasakti University, Padang ${ }^{1,2}$ \\ rahayuchichi@gmail.com¹, eliyarti58@gmail.com²
}

Received: July 10 ${ }^{\text {th }}, 2019$. Revised: August $20^{\text {th }}, 2019$. Accepted: August $23^{\text {th }}, 2019$

\author{
Keywords : \\ Physics learning materials; \\ Generative Learning; Open- \\ Ended Problem; Critical \\ Thinking Skill
}

\begin{abstract}
The subject of this research was to discribe the implementation physics learning materials based generative learning with open-ended problem approach to stimulate students' critical thinking skills. This type of research is $4 D$ consisting of four stages, in this paper discussing a review of the implementation which includes in development stage. The data collection instruments are essay tests, assessment sheets, and student competency sheets. Analysis technique carried out in three domain:cognitive design assessment uses the t test with subscale analysis of critical thinking, also using gain test analysis to see an increase in critical thinking, then the analysis for affective and psychomotor domains using descriptive statistics. Based on analysis of student's competency critical thinking skills increased by 29.9\%. with $t_{\text {count }} 19.06>t_{(0.975)(31)} 1.67$ in significance level 0.05 , also gain factor from the $1^{\text {st }}$ meeting until $4^{\text {th }}$ meeting are $\langle g\rangle_{1}=0.3,\langle g\rangle_{2}=0.4,\langle g\rangle_{3}=0.5,\langle g\rangle_{4}=0.5$ in an interval $0.3<g<0.7$ indicating significant differences. It means by using this learning material student can increase their critical thinking skill. In the affective domain, the attitudes of the learner in good categories with a class average of $76.65 \%$ and competency skills get an average of $74.18 \%$, placing this material can improve learners learning outcomes in affective competencies and skills.
\end{abstract}

\section{INTRODUCTION}

Learning activities are expected to involve students actively to interact with concrete objects. Teachers must be able to carry out education with an orientation to the activities of students in finding and setting meaning independently so that the learning process will be able to develop students' high thinking skills [1]. However, in learning activities at school, there are still problems. For this reason, observations were made to several senior high schools in the city of Padang during April-August 2015 that as an needs assessment analysis of students. Needs asessment is needed to assess and identify learning needs, 
discrepancies between expected curriculum learning and those that occur in schools in order to find the right solutions to these problems [2]. In this needs assessment analysis, the observed indicators are the level of students' understanding of Physics material, the type of learning resources that students like in learning, and the types of learning methods used in solving Physics problems. Based on the results of the analysis of the needs of students, it is known that as many as $66.66 \%$ of students stated difficulties understanding material in Physics, 59.16\% of students stated that they did not like teaching materials used in schools, and $75.55 \%$ of students stated difficulties in solving problems matter of physics.

We can see in the previous research in 2013, Djamas, Kamus and Murtiani conducted research on the analysis of the situation of physics learning activities in class X of SMAN Padang in order to develop students' critical thinking skills and characters. According to Djamas, Kamus and Murtiani that challenging learning activities to develop critical skills and character development are still not implemented in the physics learning at SMAN Padang city, and teacher's understanding of models, approaches, and the use of learning materials is still lacking, so the characteristics of Physics material and student characteristics have not been taken into consideration in determining the learning materials to be used. It can be understood that the problems in learning Physics are closely related to learning material that are not developed at school. In learning activities learning material are needed so that learning activities can take place properly and learning objectives can be achieved. In line with the opinion of Trianto that learning material are a set of learning resources used by teachers and students in learning activities [3].

In addition, based on our observation during April-August 2015 students who liked learning activities with natural phenomena $69.99 \%$ and students who liked group learning activities to solve physics problems $51.10 \%$. This requires a model and approach that can support the needs of these students. As a solution, it is expected that learning material based on generative learning models with an open-ended problem approach can overcome these problems. Generative learning models can support this through four phases of learning in it. According to Osborne and Cosgrove in Srianty that the stages of learning in the generative learning model by the introduction stage (exploration), the focusing phase, the challenge stage, and the implementation stage of the concept [4]. Generative learning models are based on the view that knowledge is obtained through the learning process that students pass through. This is in line with the opinion of Cahyaningrum, Syaifuddin, Effendi that generative learning models make students not passively accept the information [5].

Students develop critical thinking skills, one of which is when they focus their thoughts on finding a specific solution to a problem. Critical thinking is an evaluation activity, considering conclusions to be taken [6]. Another opinion states that critical thinking is the thinking needed to advance students' thinking abilities [7]. In line with the opinion of Nur, Siti, Susriyati, Endang that critical thinking is reasonable reflective thinking that focuses on deciding what to believe or do [8]. Popil also added that critical thinking is a thought that aims where individuals systematically and are accustomed to imposing intellectual criteria and standards on their thinking [9]. This means that critical thinking is an activity evaluating the conclusions to be taken [10]. By using the generative learning model, the potential possessed by students in the form of initial knowledge will be connected with new knowledge that will be taught in the learning process takes place, so that the teacher highly appreciates what potentials each student has, and what needs are needed by students in the learning process [11].

The approach used to support the generative learning model is the open-ended problem approach. An open-ended problem approach is an approach that allows students to develop their mindset according to their interests and abilities [12]. In the open-ended approach, the problem of giving open problems is not to get answers but to emphasize how students arrive at answers so students have the flexibility to express their opinions or answers actively and creatively [13]. Giving problems in the open-ended problem approach allows students to develop critical thinking skills. In line with the opinion of Badger in Husain that the open-ended is not the form of a question that demands one correct answer. It is also not a question that can accept any answer. In contrast, open-ended questions address key concepts and 
processes that go beyond specific instructions that define critical content. In general, open-ended questions require complex thinking and produce a variety of solutions [14].

Critical thinking is basically the ability to solve problems logically. Critical thinking is purposeful thinking of individuals systematically and habitually imposing criteria and intellectual standards on their minds [9]. Critical thinking is a directed and clear process that is used in mental activities such as solving problems, making decisions, persuading, analyzing assumptions, and conducting scientific research [15]. To measure critical thinking skills developed from five subscales. Philips in Djamas, Kamus, Murtiani said the five subscales are analysis, evaluation, inference, deductive reasoning, inductive reasoning. In this study, the critical thinking skills subscale can be raised in learning activities using generative learning models with an open-ended problem approach, training students to construct knowledge and find their own concepts so as to stimulate critical thinking skills students [16].

Implementation can be interpreted as the effectiveness level of success in the use of a learning device. How much learning using materials developed reaches learning effectiveness indicators [17]. In this study, researchers defined the effectiveness of learning to stimulate critical thinking skills. This effectiveness is based on all activities carried out by students, the implementation of learning syntax, the response of students to learning and learning outcomes of students. So that to describe the effective implementation of learning material can be done through measuring test scores of students, observing the learning process, evaluating students towards planned and planned formal and special learning and evaluation.

\section{METHOD}

This study uses a 4-D cycle model. This model consists of 4 stages, namely defining, designing, developing, disseminating. In this paper, we will examine the development stage. In this paper will discuss the implementation of the product being developed. The product developed is in the form of a high school physics learning device consisting of a syllabus, Learning Implementation Plan (RPP), handouts, student worksheets (LKPD), and assessment sheets on linear motion kinematics based on generative learning models with an open-ended problem approach. The instrument of this study are essay tests to measure students' critical thinking skills, attitude assessment sheets to measure student attitudes assessment, and students 'skills assessment sheets to measure students' skills assessment during the learning process. The device testing was conducted at SMAN 4 Padang. Analysis of the implementation of learning devices was carried out in the three assessment domains, namely cognitive, affective, and psychomotor domains.

Analysis of critical thinking skill

In the knowledge competency, the implementation of the learning device is directed at assessing the improvement of critical thinking skills using the pretest and posttest group design.

\begin{tabular}{|c|}
\hline $\mathrm{O}_{1} \quad \mathrm{X} \quad \mathrm{O}_{2}$ \\
Fig 1. Pretest and posttest group design [18]
\end{tabular}

Information:

$\mathrm{O}_{1}$ : pre-test learning outcomes before using the product

$\mathrm{O}_{2}$ : post-test learning outcomes before using the product

To analyze it used statistical tests (t-test). Before the t-test was carried out, a prerequisite test was carried out using the normality test and homogeneity test. The instrument for assessing critical thinking skills in the form of essay tests. Critical thinking skills consist of five subscales, 
to analyze each critical thinking subscale, using descriptive statistical analysis using the formula:

$$
N=\frac{X}{\text { maximum number of scores }} \cdot 100
$$

With $\mathrm{X}$ is the number of scores obtained by students. The calculation results obtained are then compared with the classification of critical thinking skills in table 1 below.

Table 1. Level criteria critical thinking skills based on scores obtained by students

\begin{tabular}{cc}
\hline Score Interval obtained by students & Level criteria critical thinking skill \\
\hline $0 \leq \mathrm{N}<39$ & Not Critical \\
$40 \leq \mathrm{N}<55$ & Less Critical \\
$56 \leq \mathrm{N}<65$ & Quite Critical \\
$66 \leq \mathrm{N}<79$ & Critical \\
$80 \leq \mathrm{N}<100$ & Very Critical \\
\hline
\end{tabular}

Then to see an increase in critical thinking using gain test as below:

$$
\langle g\rangle=\frac{\left\langle S_{\text {post }}\right\rangle-\left\langle S_{\text {pre }}\right\rangle}{100 \%-\left\langle S_{\text {pre }}\right\rangle}
$$

Hence:

$\langle\mathrm{g}\rangle \quad=$ gain factor

$\left\langle\mathrm{S}_{\text {post }}\right\rangle=$ average post score

$\left\langle\mathrm{S}_{\text {pre }}\right\rangle=$ average initial score

Then the criteria for increasing students' critical thinking skills based on gain factors are:

Table 2. Level increasing student critical thinking skill based on factor gain

\begin{tabular}{cc}
\hline Score of gain factor & Level increasing based on gain factor \\
\hline $\mathrm{g}>0,7$ & High \\
$0,3<\mathrm{g}<0,7$ & Medium \\
$\mathrm{g}<0,3$ & Low \\
\hline
\end{tabular}

Values in the domain of cognitive of students are said to be complete if they have reached the Minimum Completion Criteria (KKM).

Analysis of student's affective and psychomotor competency assessment

Analysis of attitude and skills competency assessment is used to determine the character of students who appear in the learning process. This assessment is to detect the characteristics that are formed in students through the learning process that they follow. This attitude and skills assessment uses attitude observation sheets and skill observation sheets during the learning process in the classroom. Data analysis by knowing the percentage of completeness using the following equation:

$$
S=\frac{B}{C} \cdot 100
$$




$$
K=\frac{B}{C} \cdot 100
$$

Information:

$S$ : attitude value

$K$ : skill value

$B$ : score obtained

$C$ : maximum score

\section{RESULTS AND DISCUSSIONS}

The implementation of learning devices is seen based on student learning outcomes in competency knowledge, attitudes, and skills. Learning will be effective if students are actively involved in organizing and finding knowledge. If students are more active, learning will be more effective.

\section{Results of Knowledge Assessment}

Data on the results of student knowledge competency assessment were obtained from daily assessments and the results of written tests of critical thinking skills at each meeting. Initially given an initial test to find out the initial knowledge of the level of critical thinking skills of students. The average score of the initial test of students was 51. The average of students' critical thinking skills in percent for the initial test was 53.2\%. Treatment with learning using the materials developed was carried out in 4 meetings. In general, the results of the assessment analysis for each critical thinking skills subscale can be seen in Table 3.

Table 3. Results of Assessment Analysis for Each Sub-Scale of Critical Thinking Skills

\begin{tabular}{|c|c|c|c|c|c|}
\hline \multirow[t]{2}{*}{ Meeting of- } & \multicolumn{5}{|c|}{ The Sub-scale of Critical Thinking Skills } \\
\hline & Analysis & Evaluation & Inference & Deductive & Inductive \\
\hline $\begin{array}{l}\text { Without Treatment: } \\
\text { Score of initial test }\end{array}$ & 73.0 & 77.0 & 65.5 & 64.3 & 61.0 \\
\hline $\begin{array}{c}\text { Score of initial test in } \\
\text { percent } \\
\text { Average }\end{array}$ & 57.0 & 60.2 & $\begin{array}{l}51.2 \\
53.2\end{array}$ & 50.2 & 47.6 \\
\hline $\begin{array}{l}\text { Level criteria critical } \\
\text { thinking skill }\end{array}$ & $\begin{array}{c}\text { Quite } \\
\text { Critical }\end{array}$ & $\begin{array}{c}\text { Quite } \\
\text { Critical }\end{array}$ & $\begin{array}{l}\text { Less } \\
\text { critical }\end{array}$ & Less critical & Less critical \\
\hline With Treatmet: & & & & & \\
\hline I & 88.0 & 87.0 & 76.0 & 75.0 & 75.0 \\
\hline II & 91.0 & 90.0 & 80.0 & 81.0 & 80.0 \\
\hline III & 88.0 & 84.0 & 81.0 & 81.0 & 81.0 \\
\hline IV & 88.0 & 88.0 & 82.0 & 83.0 & 83.0 \\
\hline In percent & 88.8 & 87.3 & 79.8 & 80.0 & 79.8 \\
\hline Average & & & 83.1 & & \\
\hline $\begin{array}{l}\text { Level criteria critical } \\
\text { thinking skill }\end{array}$ & $\begin{array}{l}\text { Very } \\
\text { Critical }\end{array}$ & Very Critical & Critical & Very Critical & Critical \\
\hline
\end{tabular}

Based on Table 3, the average percentage of students' critical thinking skills from I-IV meetings is at critical criteria to very critical. This shows that students' critical thinking skills have increased by $29.9 \%$ compared to the initial test.Then to see an increase of critical thinking skill in each meeting we can use gain-test as shows below. 
Implementation of Physics Learning Materials Based Generative Learning With Open-Ended...

Chichi Rahayu, Eliyarti

Table 4. Results of Critical Thinking Skills Assessment Analysis Using Gain Test

The Sub-scale of Critical Thinking Skills

\begin{tabular}{|c|c|c|c|c|c|c|c|}
\hline \multirow[b]{2}{*}{ Meeting of- } & \multicolumn{5}{|c|}{ The Sub-scale of Critical Thinking Skills } & \multirow[b]{2}{*}{$\langle g\rangle$} & \multirow{2}{*}{$\begin{array}{c}\text { Level } \\
\text { increasing } \\
\text { based on } \\
\text { gain } \\
\text { factor }\end{array}$} \\
\hline & Analysis & Evaluation & Inference & Deductive & Inductive & & \\
\hline I & 88.0 & 87.0 & 76.0 & 75.0 & 75.0 & 0.3 & Medium \\
\hline II & 91.0 & 90.0 & 80.0 & 81.0 & 80.0 & 0.4 & Medium \\
\hline III & 88.0 & 84.0 & 81.0 & 81.0 & 81.0 & 0.5 & Medium \\
\hline IV & 88.0 & 88.0 & 82.0 & 83.0 & 83.0 & 0.5 & Medium \\
\hline In percent & 88.8 & 87.3 & 79.8 & 80.0 & 79.8 & & \\
\hline $\begin{array}{l}\text { Level criteria } \\
\text { critical } \\
\text { thinking skill }\end{array}$ & $\begin{array}{l}\text { Very } \\
\text { Critical }\end{array}$ & $\begin{array}{c}\text { Very } \\
\text { Critical }\end{array}$ & Critical & $\begin{array}{c}\text { Very } \\
\text { Critical }\end{array}$ & Critical & & \\
\hline
\end{tabular}

Through the gain test, it was found that the increasing students 'critical thinking skills was $\langle\mathrm{g}\rangle_{1}=0.3,\langle\mathrm{~g}\rangle_{2}$ $=0.4,\langle\mathrm{~g}\rangle_{3}=0.5,\langle\mathrm{~g}\rangle_{4}=0.5$ in an interval of $0.3<\mathrm{g}<0.7$ with medium increasing level, indicating that the use of Physics learning material based on generative learning models with an open-ended problem approach can stimulate students' critical thinking skills. To see the increase in the stimulus of critical thinking skills from the use of learning devices based on generative learning models with the open-ended problem approach statistical tests were performed using the t-test. Before a statistical test with a t-test is carried out, a prerequisite test is carried out using the normality test and homogeneity test as shown in tables 5 , 6 and 7.

Table 5. Analysis of the normality test for critical thinking skills tests

\begin{tabular}{cccc}
\hline Test Data For Critical Thinking Skills & Lo & Lt & Distribution \\
\hline Before treatment (Initial Test) & 0.08 & 0.16 & Normal \\
Meeting I & 0.13 & 0.16 & Normal \\
Meeting II & 0.15 & 0.16 & Normal \\
Meeting III & 0.11 & 0.16 & Normal \\
Meeting IV & 0.09 & 0.16 & Normal \\
\hline
\end{tabular}

From Table 5 it can be seen that the value of Lo $<$ Lt for each group of data. This means that the test data for critical thinking skills come from populations that are normally distributed.

Table 6. Analysis of homogeneity tests of critical thinking skills tests

\begin{tabular}{ccccccc}
\hline $\begin{array}{c}\text { Test Data For Critical Thinking } \\
\text { Skills }\end{array}$ & $\mathbf{N}$ & $\mathbf{S 2}$ & $\boldsymbol{\alpha}$ & $\mathbf{F h}$ & $\mathbf{F t}$ & Information \\
\hline Before Treatment (Initial Test) & 32 & 57.30 & 0.05 & 1.13 & \multirow{2}{*}{1.83} & $\begin{array}{c}\text { Homogeneo } \\
\text { us }\end{array}$ \\
\hline After Treatment (Meeting IV) & 32 & 50.70 & & & & \\
\hline
\end{tabular}

From Table 6, we can see the value of Fh $<\mathrm{Ft}$ for both groups of data. This means that the test data for critical thinking skills have a homogeneous variance.

Table 7. Results of t-test analysis

\begin{tabular}{|c|c|c|c|c|c|}
\hline Test Data For Critical Thinking Skills & $\mathbf{N}$ & $\Sigma \mathbf{d}$ & Md & tcount & Ttable \\
\hline Before Treatment (Initial Test) & & & & & \\
\hline After Treatment (Meeting IV) & & & & & \\
\hline
\end{tabular}

Based on the results of the calculation obtained $t_{\text {count }}$ is 19.06 while the value of $t_{\text {table }}$ with a real level of 0.05 and degree of freedom $=31$ is obtained $t_{(0.975)(31)}$ of 1.67. Test criteria accept $\mathrm{H}_{0}$ if $-\mathrm{t}_{\text {table }}<\mathrm{t}$ count 
$<t_{\text {table }}$, while for other prices $\mathrm{H}_{0}$ is rejected. From the calculation obtained by $t_{\text {count }}>t_{\text {table }}$, it means that $t_{\text {count }}$ is outside $\mathrm{H}_{0}$ 's reception area, so the working hypothesis $\mathrm{H}_{\mathrm{i}}$ is accepted. This means that there are significant differences in improving students' critical thinking skills. This difference is caused by differences in treatment, namely before and after the use of Physics learning materials based on generative learning models with an open-ended problem approach. In general, student competency has increased. This can be seen in the increase in the average value (classical) and the percentage of completeness of students. The results of the knowledge competency analysis can be seen in Table 8 .

Table 8. Results Assessment of the KKM of knowledge competence

\begin{tabular}{cccccc}
\hline No & Meeting & $\begin{array}{c}\text { Score } \\
\text { average }\end{array}$ & $\begin{array}{c}\text { Number } \\
\text { students that } \\
\text { completed } \\
\text { score of KKM }\end{array}$ & $\begin{array}{c}\text { Number students } \\
\text { that uncompleted } \\
\text { score of KKM }\end{array}$ & $\begin{array}{c}\text { level } \\
\text { completeness } \\
\text { in percent }\end{array}$ \\
\hline 1 & 1st & 78.16 & 24 & 8 & 75.00 \\
2 & 2nd & 83.25 & 25 & 7 & 78.12 \\
3 & 3rd & 82.53 & 26 & 6 & 81.25 \\
4 & 4th & 84.03 & 27 & 5 & 84.37 \\
\hline \multicolumn{2}{r}{ The average } & 81.99 & & & 79.68 \\
\hline
\end{tabular}

Based on Table 8, it can be seen that the average student learning outcomes for knowledge competencies are in a good category. The average value of the students for four meetings was 81.99 with a percentage of completeness above KKM 79.68\%. This shows that implementation of physics learning material based on generative learning models with an open-ended problem approach can improve student learning outcomes in knowledge competencies by stimulating students' critical thinking skills.

Analysis of student learning outcomes in knowledge competencies showed the average percentage of critical thinking skills for each indicator of critical thinking skills, about $88.75 \%$ analysis, $87.25 \%$ evaluation, $79.75 \%$ inference, $80 \%$ deductive and $79.5 \%$ inductive. The average percentage of critical thinking skills from this $1^{\text {st }}-4^{\text {th }}$ meeting is in the critical criteria to very critical. This means that students 'critical thinking skills have increased compared to students' critical thinking skills in the initial test, that are $57 \%$ analysis, $60.16 \%$ evaluation, $51.17 \%$ inference, $50.195 \%$ deductive and $47.66 \%$ inductive. Based on the results of the analysis of critical thinking skills through the gain test shows that gain factor from the $1^{\text {st }}$ meeting until the $4^{\text {th }}$ meeting are $\langle\mathrm{g}\rangle_{1}=0.3,\langle\mathrm{~g}\rangle_{2}=0.4,\langle\mathrm{~g}\rangle_{3}=0.5,\langle\mathrm{~g}\rangle_{4}=0.5$ in interval $0.3<\mathrm{g}<0.7$. Meaning there's increasing of student critical thinking skill in medium level by using this learning material. Also result from t-test analysis obtained at the real level $\alpha=0.05$ and $\mathrm{dk}=62$ from the distributed $t_{\text {table }}$ obtained $t_{(0.95 ; 62)}=1.67$ acceptance of $H_{0}$ if $t<t{ }_{(1-\alpha)}$ or $t<1.67$. Because $t_{\text {count }}=19.06$ which means $t_{\text {count }}>t_{\text {table, }}$, is outside the reception area $\mathrm{H}_{0}$. So, it can be concluded that the working hypothesis $\mathrm{H}_{\mathrm{i}}$ is accepted, meaning there are significant differences in improving students' critical thinking skills. This difference is caused by differences in treatment, thats are before and after the use of Physics learning materials based on generative learning models with an open-ended problem approach.

This is due to the steps of learning activities in this learning material based on generative learning models with an open-ended problem directing students to develop a mindset in solving problems so that they can stimulate students' critical thinking skills. In line with Widana's opinion critical thinking is a directed and clear process used in mental activities such as solving problems, making decisions, persuading, analyzing assumptions, and carrying out scientific work [15]. There are four stages in this learning step. Starting with the preliminary stage to encourage students to explore. Learners can explore using objects, situations or conditions that are familiar with the lives of learners so that the cognitive burden often faced by students when meeting things that are not familiar with them can be reduced [19]. Then the focusing stage, it is supported by the open-ended problem approach where the teacher motivates students and asks open questions. Open questions are a critical foundation of thought which in turn is a source of knowledge formation and must, therefore, be taught as a framework for all learning [20]. 
Giving open problems in the open-ended problem approach allows students to develop critical thinking skills. In line with the opinion of Badger in Husain that open-ended problems not only offer one right answer but also demand concepts, processes, and skills in solving problems that are realized by critical thinking [14]. Students can explore their initial knowledge and then develop learning experiences. In line with the opinion of Wulandari and Gusti that the initial knowledge possessed by students is the result of an exploration of the knowledge, ideas, or conceptions obtained from everyday experience [11]. Then at the challenge stage students can carry out science processes in the form of experimental activities, literature studies, and discussions. According to Ariani, Candiasa, Marhaeni at this stage learners had the opportunity to investigate various strategies and ways they believed [21]. This will make students get the opportunity to express their ideas [4]. In this phase, the activities of students are solving practical questions based on scientific concepts, or presenting solutions to problems in class friends, and discussing scientific views in different situations. The concept of helping students simplify and summarize information and improve memory efficiency, communication and use of student time [21]. Thus, the learning done can stimulate students' critical thinking skills.

The average mastery learning classically also shows good criteria with a percentage of completeness of $79.687 \%$, where the highest completeness at the fourth meeting is $84.375 \%$. The average value of student learning outcomes is also classified as good, about 81.99 which is above the KKM, which is 78 . Even though the average value of students in the $3^{\text {rd }}$ meeting was 82.53 , it was slightly lower than the average score of students in the second meeting of 83.25. This is because students are still unfamiliar with the steps in the generative learning model with the open-ended problem approach. Students pay less attention to the lesson. Some of them are still talking about the camp with their friends while working on the student worksheet (LKPD) and handouts so that students are less concerned about the lesson [22]. A conducive learning atmosphere can increase the concentration of students in learning [23]. Concentration is a concentration of mental functions on an object such as the concentration of mind, attention and so on [24]. The concentration of learning can be disrupted because it is influenced by several factors. Nugroho also states that the factors that cause disruption of students' concentration of learning are the lack of self-motivation, the atmosphere of a non-conducive learning environment and the health conditions of students [25].

However, it is seen from the average percentage of the four meetings as a whole is $79.687 \%$, indicating an increase in the percentage of completeness. These results provide a conclusion that the devices developed can improve students' knowledge competencies. Data analysis on attitude competency showed an increase at each meeting. This attitude assessment is done to see the extent to which students practice the teachings of their religion through the learning process and how the social attitudes of the students. This is indicated by the average percentage of 72.75 and 72.5 . This is because students are not familiar with learning using the generative learning model with an open-ended problem approach. However, overall it can be said that by using learning materials based on generative learning models with open-ended problem approaches, students' attitudes are good in the learning process. In line with the opinion of Zakirman, Lufri, Khairani that the quality of learning can be improved by changing the pattern of activities/learning steps [26].

\section{Attitude Assessment Results}

There are two types of attitude competency assessment in this study, namely observation of the spiritual attitudes of students and the social attitudes of students. Assessment of student attitudes was carried out at each meeting by one observer through the observation sheet of the attitude of the students. This attitude assessment is done to see the extent to which students practice the teachings of their religion through the learning process and how the social attitudes of the students. Data obtained from observation sheets to observe the spiritual attitudes and social attitudes of students during the learning process. The results of the attitude assessment are presented in Table 9. 
Table 9. Result of Attitude Assessment

\begin{tabular}{ccccccc}
\hline \multirow{2}{*}{ Observation Aspect } & \multicolumn{3}{c}{$\begin{array}{c}\text { Student attitude score in percent } \\
\text { for each meeting }\end{array}$} & \multirow{2}{*}{$\begin{array}{c}\text { Average } \\
\text { score }\end{array}$} & $\begin{array}{c}\text { Level Student's } \\
\text { competency based } \\
\text { on average score }\end{array}$ \\
\cline { 2 - 5 } & I & II & III & IV & & \\
\hline Pray & 80.00 & 82.00 & 85.00 & 88.00 & 83.75 & Very good \\
Curiosity & 67.00 & 73.00 & 74.00 & 77.00 & 72.75 & Good \\
Accuracy & 71.00 & 73.00 & 72.00 & 74.00 & 72.50 & Good \\
Responsible & 76.00 & 77.00 & 78.00 & 79.00 & 77.50 & Good \\
Communicate & 74.00 & 75.00 & 76.00 & 82.00 & 76.75 & Good \\
\hline Average score in percent & 73.60 & 76.00 & 77.00 & 80.00 & 76.65 & Good \\
\hline
\end{tabular}

Based on Table 9 shows that overall, students' attitudes are in a good category with a class average of 76.65 , meaning that implementation this learning material are effective used in learning. This states that the competency of students' attitudes increases at each meeting. Starting from $1^{\text {st }}$ meet to $4^{\text {th }}$ meet.

Skills Assessment Results

Learning outcomes of students in competency skills are taken from the activities of students in conducting practical activities. In summary, can be seen in Table 10.

Table 10. Results of Skills Assessment

\begin{tabular}{|c|c|c|c|c|c|c|}
\hline \multirow[t]{2}{*}{ Observation Aspect } & \multicolumn{4}{|c|}{$\begin{array}{l}\text { Student's practical skill score in } \\
\text { percent for each meeting }\end{array}$} & \multirow{2}{*}{$\begin{array}{l}\text { Average } \\
\text { Score }\end{array}$} & \multirow{2}{*}{$\begin{array}{l}\text { Level Student's } \\
\text { competency based on } \\
\text { average score }\end{array}$} \\
\hline & 1st & 2nd & 3rd & 4th & & \\
\hline $\begin{array}{l}\text { Assembling Experimental } \\
\text { tools and Materials }\end{array}$ & 72.00 & 80.00 & 81.00 & 75.00 & 77.00 & Very good \\
\hline Do observations & 70.00 & 74.00 & 75.00 & 77.00 & 74.00 & Good \\
\hline $\begin{array}{l}\text { Participation in each step } \\
\text { of the experiment }\end{array}$ & 68.00 & 69.00 & 71.00 & 77.00 & 71.25 & Good \\
\hline $\begin{array}{c}\text { The accuracy of using a } \\
\text { tool }\end{array}$ & 72.00 & 71.00 & 74.00 & 73.00 & 72.50 & Good \\
\hline $\begin{array}{c}\text { Analyze experimental } \\
\text { data }\end{array}$ & 71.00 & 76.00 & 78.00 & 80.00 & 76.25 & Good \\
\hline $\begin{array}{l}\text { Record the experimental } \\
\text { results }\end{array}$ & 72.00 & 74.00 & 74.00 & 74.00 & 73.50 & Good \\
\hline Present group reports & 69.00 & 74.00 & 73.00 & 83.00 & 74.75 & Good \\
\hline Average score in percent & 70.57 & 74.00 & 75.14 & 77.00 & 74.18 & Good \\
\hline
\end{tabular}

Based on Table 10, it shows that all indicators observed in the experimental activities have been carried out properly. The value of learning outcomes in skills competencies all aspects got an average of 74.18. If guided by the effective category table, then this average value is in the interval 61-80 in the good category.

The average value of attitude learning outcomes is 76.65 which can be categorized as good. From the observers' observations in general during the learning process, some students have cultivated a spiritual attitude that is shown by praying before learning, a social attitude that is shown by curiosity, thoroughness, responsibility, and communication in carrying out the learning process. It can be said that the learning device developed can further improve student learning outcomes in attitude competencies if the application of this learning device is developed for further material. The results of the practical skills assessment analysis showed an average score on skills competency 74.18. The aspect of participation in each of the experimental steps and the accuracy aspects of using the instrument showed a lower average than the other aspects of skills. This is indicated by the average percentage of 71.25 and 72.5. This is because students are not accustomed to using practical materials and some students still lack focus in practical activities. However, from observers' observations in general during the experiments, some students were enthusiastic in carrying out the practicum. This proves that the learning 
Implementation of Physics Learning Materials Based Generative Learning With Open-Ended... Chichi Rahayu, Eliyarti

experience gained during learning is meaningful for students to develop their mindset.

\section{CONCLUSION AND SUGGESTION}

Physics learning devices based on generative learning models with open-ended problem approaches that meet the effective criteria with an average percentage of 81.99 for the knowledge aspect, 76.65 for the attitude aspect and 74.65 for the skill aspect. In addition, the learning devices produced can stimulate students' critical thinking skills shown through statistical tests where tcount>t table is 19.06>1.67. This shows that there are significant differences in improving students' critical thinking skills before and after treatment. For students, Physics learning devices based on generative learning models with open-ended problem approaches can improve student competency. Both competency knowledge, attitudes, and skills. In addition, this learning device can also activate and optimize the potential of students. For teachers, Physics learning devices based on generative learning models with open-ended problem approaches can be used by teachers as a tool in learning activities, especially in Physics subjects.

\section{ACKNOWLEDGMENTS}

Authors wishing to acknowledge assistance or encouragement from colleagues, special work by technical staff or financial support from organizations should do so in an unnumbered Acknowledgments section immediately following the last numbered section of the paper.

\section{REFERENCES}

[1] Y, Abidin. (2014). Desain Sistem Pembelajaran dalam Konteks Kurikulum 2013. Bandung : PT. Radika Aditama,.

[2] Nurjannah, N. (2018). Analisa Kebutuhan Sebagai Konsep Dasar dalam Pengembangan Kurikulum Bahasa Arab di MAN Curup. ARABIYATUNA: Jurnal Bahasa Arab, 2(1): 49-72.

[3] Trianto. (2012). Model Pembelajaran Terpadu. Jakarta: Bumi Aksara.

[4] Srianty, S., Samad, A., \& Patandean, A. J. (2010). Upaya Meningkatkan Kemampuan Berpikir Kritis Fisika Siswa Kelas Xi Ipa3 Sma Negeri 1 Bungoro Melalui Model Pembelajaran Generatif. Jurnal Sains dan Pendidikan Fisika, 7(1).

[5] Cahyaningrum, V. D., Syaifuddin, M., \& Effendi, M. M. M. (2018, January). The Effects of the Application of Generative Learning Model with Brainstorming Technique on Students' Mathematical Reasoning and Communication Abilities. In University of Muhammadiyah Malang's 1st International Conference of Mathematics Education (INCOMED 2017). Atlantis Press.

[6] Sastrini, M., Garminah, N. N., Hum, M., \& Wibawa, I. M. C. (2014). Pengaruh Model Pembelajaran Generatif Terhadap Keterampilan Berpikir Kritis IPA Siswa SD Kelas V Gugus III Kecamatan Tejakula. MIMBAR PGSD Undiksha, 2(1).

[7] Changwong, K., Sukkamart, A., \& Sisan, B. (2018). Critical thinking skill development: Analysis of a new learning management model for Thai high schools. Journal of International Studies Vol, 11(2): 11-2.

[8] Fuad, N. M., Zubaidah, S., Mahanal, S., \& Suarsini, E. (2017). Improving Junior High Schools' Critical Thinking Skills Based on Test Three Different Models of Learning. International Journal of Instruction, 10(1): 101-116.

[9] Popil, I. (2011). Promotion of critical thinking by using case studies as teaching method. Nurse education today, 31(2): 204-207.

[10] Abbasi, A., \& Izadpanah, S. (2018). The Relationship Between Critical Thinking, its Subscales and Academic Achievement of English Language Course: The Predictability of Educational Success Based on Critical Thinking. Academy Journal of Educational Sciences, 2(2): 91-105.

[11] Wulandari, I. G. A. A., Dantes, N., Tika, I. N., \& Si, M. (2014). Pengaruh Model Pembelajaran Generatif Terhadap Minat Dan Hasil Belajar IPA Pada Siswa Kelas V SD (Studi Kasus Di Gugus 
Letkol Wisnu Denpasar Utara). PENDASI: Jurnal Pendidikan Dasar Indonesia, 4(1).

[12] ES, Y. R., \& Harta, I. (2014). Keefektifan pendekatan open-ended dan CTL Ditinjau dari hasil belajar kognitif dan afektif. Jurnal Riset Pendidikan Matematika, 1(1): 113-126.

[13] Murni. (2013). Open-Ended Approach to Learning to Improve Students Thinking Skills in Banda Aceh. International Journal of Independent Research and Studies, 2(2): 95-101.

[14] Husain, H., Bais, B., Hussain, A., \& Samad, S. A. (2012). How to construct open ended questions. Procedia-Social and Behavioral Sciences, 60: 456-462.

[15] Widana, M., Suhandana, A., \& Atmadja, B. (2013). Pengaruh Model Pembelajaran Berorientasi Pemecahan Masalah Open-Ended Terhadap Kemampuan Berpikir Kritis Dan Hasil Belajar Biologi Siswa Kelas VII SMP Negeri 1 Kintamani. Jurnal Administrasi Pendidikan Indonesia, 4(1).

[16] Djamas, D. (2013). Analisis Situasi Aktivitas Pembelajaran Fisika Kelas X SMAN Kota Padang Dalam Rangka Pengembangan Keterampilan Dan Karakter Berpikir Kritis Siswa. Eksakta, 2.

[17] Yannidah, N., Kurniawan, L., \& Aunillah. (2013). Development Devices With Aptitude Treatment Interaction In Effectiveness Mathematics Learning. Jurnal Pendidikan Matematika STKIP PGRI Sidoarjo, 1(1): 1-12.

[18] Arikunto, S. (2008). Dasar-Dasar Evaluasi Pendidikan. Jakarta: Bumi Aksara.

[19] Kartika, E. (2015). Kreativitas Siswa SMP RSBI dalam Pemecahan dan Pengajuan Masalah Matematika Berdasarkan Open-Ended Problem Picture Ditinjau dari Kemampuan Matematika. APOTEMA: Jurnal Program Studi Pendidikan Matematika, 1(2): 36-46.

[20] Karakoc, M. (2016). The significance of critical thinking ability in terms of education. International Journal of Humanities and Social Science, 6(7): 81-84.

[21] Ariani, N. M. D., Candiasa, I. M., Kom, M. I., \& Marhaeni, A. N. (2014). Pengaruh Implementasi Open-Ended Problem Dalam Pembelajaran Matematika Terhadap Kemampuan Pemecahan Masalah dengan Pengendalian Kemampuan Penalaran Abstrak. Jurnal Penelitian dan Evaluasi pendidikan Indonesia, 4.

[22] Rahayu, C., \& Festiyed, F. (2018). Validitas Perangkat Pembelajaran Fisika SMA Berbasis Model Pembelajaran Generatif Dengan Pendekatan Open-Ended Problem Untuk Menstimulus Keterampilan Berpikir Kritis Peserta Didik. Jurnal Pendidikan Fisika, 7(1): 1-6.

[23] Zakirman, Z., \& Rahayu, C. (2018). Popularitas WhatsApp sebagai media komunikasi dan berbagi informasi akademik mahasiswa. Shaut Al-Maktabah: Jurnal Perpustakaan, Arsip dan Dokumentasi, 10(1): 27-38.

[24] Djamarah, S, B. (2008). Psikologi Belajar. Jakarta: Rineka Cipta.

[25] Nugroho, W. (2007). Belajar Mengatasi Hambatan Belajar. Surabaya: Prestasi Pustaka.

[26] Zakirman, Z., Lufri, L., \& Khairani, K. (2019, January). Factors Influencing the Use of Lecture Methods in Learning Activities: Teacher Perspective. In International Conference on Islamic Education (ICoIE 2018). Atlantis Press. 